\title{
Wars Do not Kill Only with Guns: A Case of Rabies in a Syrian Refugee
} Savaşlar Yalnızca Silahlarla ÖIdürmez: Suriyeli Bir Mültecide Kuduz Olgusu

\author{
Çiğdem YILDIRIM ${ }^{1}$, Bilgin ARDA ${ }^{1}$, ilhan UZ2 ${ }^{2}$ Mehmet UYAR ${ }^{3}$, Murat ERSEL2, Tansu YAMAZHAN1, Nil ÜNAL4, Müge FIRAT ${ }^{4}$, \\ Sercan ULUSOY1, Oğuz Reşat SiPAHi1 \\ ${ }^{1}$ Ege University Faculty of Medicine, Department of Infectious Diseases and Clinical Microbiology, Izmir, Turkey \\ 2Ege University Faculty of Medicine, Department of Emergency Medicine, Izmir, Turkey \\ ${ }^{3}$ Ege University Faculty of Medicine, Department of Anaesthesiology and Reanimation, Izmir, Turkey \\ ${ }^{4}$ Republic of Turkey Ministry of Food, Agriculture and Livestock-Etlik Veterinary Control Central Research Institute, Rabies Diagnosis Laboratory, \\ Ankara, Turkey
}

Keywords: Zoonotic diseases, infectious diseases, dog bite, vaccination, prophylaxis

Anahtar Kelimeler: Zoonotik hastalıklar, bulaşıcı hastalıklar, köpek ısırığı, aşılama, profilaksi

\section{Dear Editor,}

Despite developments in medicine, rabies remains nearly 100\% morta ${ }^{[1,2]}$. In this paper, we present a fatal case of rabies in a Syrian refugee who had been bitten by a dog in Syria and developed rabies in Turkey.

A 28-year-old Syrian man admitted to the Emergency Service with a 2-day history of shortness of breath, difficulty in swallowing and muscle weakness. He had been living in Turkey as a refugee for three years but had visited Syria three times in the previous 12 months. He had a history of a dog bite on the posterior of his left foot, two months previously in Syria. The patient had killed the dog after being bitten. He had no history of rabies vaccination at the time of the dog bite. However, he had received antibacterial prophylaxis. His neurological examination was also normal except lack of Achilles deep tendon reflex. His laboratory findings were as follows; leukocytes: $5970 / \mathrm{mm}^{3}$ neutrophils: $71.3 \%$ and C-reactive protein: $0.12 \mathrm{mg} / \mathrm{dL}$. Cranial computed tomography and contrast-enhanced cranial magnetic resonance imaging were found to be normal. After 17 hours in the emergency department, the patient attacked the nurses and doctors on duty, who were also immunized with rabies vaccine after the event. Afterwards, the patient was sedated and intubated. Lumbar puncture revealed no leukocyte, protein level of $35 \mathrm{mg} / \mathrm{dL}$ and glucose level of $145 \mathrm{mg} / \mathrm{dL}$. Cerebrospinal fluid (CSF) culture and multiplex polymerase chain reaction (PCR) for common viral agents did not show any pathogen. His specimens for rabies (serum, CSF, saliva, nuchal skin biopsy) were sent to Etlik Veterinary Control Central Research Institute, Rabies Diagnosis Laboratory in Ankara for rabies virus diagnostic evaluation. Viral RNA was positive in saliva sample with a RNA concentration of $229.2 \mathrm{ng} / \mu \mathrm{L}$ and with a crossing point value of 29.70 by real time PCR. Viral RNA was negative in CSF with a RNA concentration of $0.1 \mathrm{ng} / \mu \mathrm{L}$ and in nuchal skin biopsy with a RNA concentration of $1.7 \mathrm{ng} / \mu \mathrm{L}$ by real time PCR. No antibody titer was detected in the serum by fluorescent antibody virus neutralization test. Hypotension and pneumonia were detected on his examination after 12 hours and meropenem and linezolid were started. The patient was transferred to the isolation room in the intensive care unit. However, despite all efforts, he had cardiac arrest at the end of 48-h follow-up. After death, the brain sample was

Cite this article as: Yıldırım Ç, Arda B, Uz I, Uyar M, Ersel M, Yamazhan T, Ünal N, Firat M, Ulusoy S, Sipahi OR. Wars Do not Kill Only With Guns: A Case of Rabies in a Syrian Refugee. Mediterr J Infect Microb Antimicrob. 2017;6:18. 
found to be rabies-positive by fluorescent antibody test which is the gold standard diagnostic method for rabies ${ }^{[1,2]}$.

Millions of people were displaced because of civil war which has led to more than 100000 deaths in Syria. As of June 2013, two in every five hospitals were out of service. Lack of power has forced many hospitals to operate in almost impossible conditions. World Health Organization estimates that some 80000 doctors have emigrated, leaving just 37000 in Syria. The ongoing war in Syria combined with the shortage of doctors has taken a toll on the health infrastructure in that country. The case received antibiotic prophylaxis but no rabies vaccine or immunoglobulin. Even preventable diseases with vaccines such as polio, rabies and measles have resurfaced in Syria ${ }^{[3-6]}$. In summary, imported vaccine-preventable diseases such as rabies, polio and measles are now seen in Turkey. These diseases should be included in the differential diagnosis for Syrian refugees and a careful and detailed clinical history should be taken. Notification of this disease to the Directorate of Health should not be forgotten. The presented case clearly depicts that wars do not kill only with guns. The lack of infrastructures during the war seems to have caused a preventable death.

Ethics

Informed Consent: Not needed.

Peer-review: Externally and internally peer-reviewed.

\section{Authorships Contributions}

Data Collection or Processing: Ç.Y., B.A., I.U., M.U., M.E., T.Y., N.Ü., M.F., S.U., O.R.S., Analysis or Interpretation: Ç.Y., B.A., I.U., M.U., M.E., T.Y., N.Ü., M.F., S.U., O.R.S., Literature Search: Ç.Y., O.R.S., Writing: Ç.Y., O.R.S.

Conflict of Interest: No conflict of interest was declared by the authors.

Financial Disclosure: The authors declared that this study received no financial support.

\section{References}

1. Büke M. Rabies. Turkiye Klinikleri J Int Med Sci. 2006;2:46-55

2. Büke M, Karakartal G, Günhan C, Serter D, Yüce K, Otkun M. Epidemiologic and clinical evaluation of 49 rabies cases in Aegean Region. Infeksiyon Derg. 1987:1:69-74.

3. Stone-Brown K. Syria: a healthcare system on the brink of collapse. BMJ. 2013;347:7375

4. Arie S. Child vaccination campaigns are suspended in Syria after 15 infants die. BMJ. 2014;349:5791.

5. Elamein $M$, Bower $H$, Valderrama $C$, Zedan D, Rihawi $H$, Almilaji $K$, Abdelhafeez M, Tabbal N, Almhawish N, Maes S, AbouZeid A. Attacks against health care in Syria, 2015-16: results from a real-time reporting tool. Lancet. 2017:390:2278-86.

6. van Berlaer G, Elsafti AM, Al Safadi M, Souhil Saeed S, Buyl R, Debacker $M$, Redwan $A$, Hubloue I. Diagnoses, infections and injuries in Northern Syrian children during the civil war: A cross-sectional study. PLoS One. 2017:12:e0182770. 